\title{
El dinamismo transformador del agua y de la luz en Atisbos de luz de Bella Clara Ventura
}

\section{Transformative Dynamics of Water and Light in Atisbos de Luz by Bella Clara Ventura}

\author{
Jorge Chen Sham \\ Universidad de Costa Rica, Costa Rica \\ jorgechsh@yahoo.com
}

Resumen • En Atisbos de luz (2007), la poeta colombomexicana Bella Clara Ventura nos invita a sopesar y a valorar el dinamismo transformador de la luz en su complemento con el agua fecunda y fluyente. Ésta es la clave no sólo para poder ingresar en el universo poético trazado como una aventura de iniciación hacia la luminosidad del cosmos, sino también para emprender el camino de una iniciación estética que se propone como indagación y reflexión, abierta a inquirir el cosmos y la escritura poética.

Palabras clave: Bella Clara Ventura, poesía colombiana, hermenéutica, simbolismo de la luz y del agua, Gaston Bachelard.

\begin{abstract}
In Atisbos de luz (2007) the Colombian-Mexican poet Bella Clara Ventura invites the reader to ponder and appraise the transformative dynamics of light in relation to a fecund, flowing water. This is not only the key to enter a poetic world presented as an adventure of initiation into the luminosity of the cosmos, but it is also the first step in the journey of an aesthetic initiation through inquiry and reflection for comprehending the universe and poetic writing.
\end{abstract}

Key words: Bella Clara Ventura, Colombian poetry, hermeneutics, symbolism of light and water, Gaston Bachelard. 
La poeta colombomexicana Bella Clara Ventura nos presenta, en su poemario Atisbos de luz (2007), esa dimensión inefable que pone no sólo la imaginación poética sino también la configuración del elemento fuego en el centro de su indagación reflexiva. Del fuego transmutador de la alquimia a la combustión purificadora de la que se renace como el ave fénix o al fuego abrasador en el que se consumen los amantes en la erótica perfecta, este elemento apela a la absolutización de la poesía en tanto son indisolubles; en Ventura, su capacidad visionaria y la percepción máxima de un cosmos en transformación están al orden del día. Cobra sentido entonces, en el poemario, la convocatoria de esa comprensión fundamental que el simbolismo de la luz posee para nuestro imaginario occidental.

En la manera en que se estructura la experiencia de esa luminosidad en Atisbos de luz, que la onomástica misma del nombre de la poeta ya prefigura, Bella Clara Ventura se propone plantearnos una experiencia poética caracterizada como un acto abierto constantemente a una comprensión intuitiva e integradora, desde el momento en que pone su poemario bajo la protección benéfica de la luz. No hay motivo más elocuente en la teología, en la filosofía y en la poesía que arroparse de la luminosidad y ser guiados por esa aventura, esa travesía por la alteridad y la subjetividad, para hacer perceptible el universo de lo sensible. Ya lo planteaba con gran acierto Marie-Christine Séguin, a la que considero la mejor estudiosa de la hermenéutica poética que nos propone Gaston Bachelard al ámbito hispánico, cuando afirmaba que el imaginario del fuego se debate entre la seducción y la intimidad y convoca «une intensité interne qui rapproche le feu du féminin» (Séguin, 385). Como artífice del lenguaje y forjadora en el taller del alquimista, el fuego en su variante de la luz le devuelve a Bella Clara Ventura la especularidad de su condición de poeta, signada así para transformarla y pulir su escritura, pues ella intuye y "appelle au pouvoir intérieur du feu» (Séguin, 385). Sin embargo, lo curioso es constatar la amalgama o la aleación que busca entre la luz y el motivo de las aguas, lo cual parece contradictorio a primera vista.

\section{EL DINANISMO TRANSFORMADOR DE LA LUZ Y DEL AGUA: EL SIMBOLISMO ACUÁTICO}

Ahora bien, la luz y las aguas no están en oposición, más bien se complementan con la finalidad de subrayar las transmutaciones que suceden en el cosmos. Recordemos que en esa gran fragua/laboratorio que es la creación poética, la alquimia necesita del agua y del fuego para que se produzcan las transformaciones de la materia, y es gracias a las visiones producidas por el mercurio o el sulfuro que se permite ese diálogo espiritual y revelador (Pariente, 228). En él, el poeta se encuentra y convoca las maravillas del lenguaje; se le revela, pues, la dimensión creadora y trascendente de su trabajo de escritura, gracias al cual puede renacer. Ese nacimiento maravilloso se narra y se pone en escena en el poema "Rocíos», en donde es obvia la referencia al famoso cuadro El nacimiento de Venus, de Sandro Botticelli. En una suerte de transposición artística propia del Ut Pictura Poesis, el yo lírico de «Rocíos» se reconoce en la gracia de haber recibido la Poesía y por eso puede engendrar y "nacerse», es decir, puede vislumbrar su nacimiento o, en otros términos, procrearse para ver su engendramiento, y ello solamente la palabra poética lo realiza performativamente (Lara-Martínez, 177-178). Veamos el poema: 
Enarbolan las crestas de las olas.

La luz succiona del océano la sal.

La transforma en ternura/mientras me desvanezco

en los hongos marinos/ que amasan la comida

de tiempos por venir.

Diluyo las aguas entre mis dedos,

algas de luz fluyen (Ventura, 55)'.

El dinamismo de las aguas marinas sugiere un mar en movimiento en la metonimia («las crestas de las olas»), mientras ocurre la evaporación/condensación del agua para que se produzca una nueva materia, «la sal», en la que participa «la luz» del sol como energía que transforma, a causa de la condensación, el estado líquido en sólido. Pero esta metamorfosis de los elementos es concomitante con la que se gesta en el yo poético, pues ella también se vuelve incorpórea en la acción del verbo «me desvanezco». Se trata de dos acciones que ocurren complementariamente a partir de esa capacidad de transformación de la materia:

$$
\begin{aligned}
\text { La luz } \rightarrow \text { succiona } & \\
\stackrel{\text { transforma }}{\rightarrow} & \text { la sal } \\
& \rightarrow \text { me desvanezco } \\
& \rightarrow \text { Diluyo }
\end{aligned}
$$

El ciclo se completa de esta manera, a causa a la energía que todo lo altera y cambia. Así, si el agua del océano se convierte en "sal», el yo lírico de "Rocíos» experimenta una metamorfosis por la cual no sólo tiene esa capacidad mágica de crear (en la sinécdoque «Diluyo las aguas entre mis dedos»), sino también se revela su nuevo estado, en el que se conjuga fuego y agua en la metáfora «algas de luz fluyen». La esencia de dicha metamorfosis se expone bajo el principio de un nuevo nacimiento, en el que la apertura de la ostra de la que surge esa perla radiante que es Venus permite el vínculo intertextual con el cuadro de Botticelli. De las profundidades del mar salado surge y renace la hablante lírica transformada por esa energía que ahora le permite crear:

Como una Venus surjo.

Me instalo en cada perla/ para hacer

el rosario de las alegrías,

el estuario de caramelos (55).

Las referencias a la poesía están connotadas en dos imágenes que remiten al lenguaje, en sus asociaciones con lo cromático y el esplendor del orfebre (la sinestesia «el rosario de las alegrías») y con el dulce sabor de la cocina («el estuario de caramelos»). Por lo anterior, el yo lírico se mira como una poeta en el poder transformador que su palabra provoca. "Rocíos» termina entonces en esa apoteósica confirmación del destino trascendente del yo lírico en tanto poeta, así como de su vocación a la luz y a la belleza:

Bajo la ronda de los rayos/ buceo latitudes.

Cristalizo los sollozos/ de la antigua energía

y permito que mi corazón/ de niña-sirena

reciba/ de la luz la bendición (55).

Ordeno el poema en forma diferente a la de la edición original, pues en ella los versos aparecen más bien centrados. 
Con esa apelación a la inmensidad y a la verticalidad de la percepción sensorial, el poema nos invita a compartir la experiencia transformadora que la luz vivificadora extiende sin límites, pues cubre lo superior («Bajo la ronda de rayos») y lo inferior («buceo latitudes»). Se trata, como plantea tan sugestivamente Claudie Balavoine, del dominio del mar y el triunfo del nadar/navegar (79-80) en la acción de bucear, pues mar y cielo le son propicios a la nueva «Venus», que puede así bogar y sortear las aguas, lo cual permitirá a Bella Clara Ventura proponernos, en los poemas que analizaremos a continuación, un mar tranquilo y favorable, con «le même signe correcteur du navire indemne» (Balavoine, 86). Y en este final del poema, llama poderosamente la atención esa autorrepresentación del yo lírico en "niña-sirena», cuyo poder de seducir y cautivar es innegable, aunque Ventura elimina el elemento negativo que poseen las sirenas para rescatar su belleza y su luminosidad ${ }^{2}$. Pero la referencia a ese cuerpo ambiguo de niña y de mujer no puede pasar tampoco desapercibida, porque su remisión al tópico de "La anciana y la moza", de hondo calado en el pensamiento de Occidente, contribuye a reforzar la idea del rejuvenecimiento y de la renovación ${ }^{3}$ que sufre el yo lírico femenino en «Rocíos», bajo los signos del mar y de la luz.

Transida de esa manera para convertirse en poeta que domina los secretos de la materia y de su transformación, no es casual que el dinamismo del agua y la transformación de la luz se encuentren íntimamente entrelazados en Atisbos de luz. Como decíamos anteriormente, el tópico del mar tempestuoso se neutraliza en esta conjunción luz/aguas. En «Viento a babor», Bella Clara Ventura retoma la metáfora náutica que, desde la Antigüedad grecolatina, se relacionará con la técnica de la navegación y el dominio que debe tener el marino para sortear sus peligros y llegar a buen puerto. Recordemos con Luc Torres que se trata de esa metáfora acuática «de la navigation comme symbole de la traversée de la vie terrestre» (110). En el comienzo del poema, se dibujan los elementos sustanciales en la comparación que establece el yo lírico:

Soy la proa que el faro sigue,/ el adentro de una navegación donde cada viajero/ busca su polar estrella (47).

Llegar a buen puerto, buscar la guía para arribar a él, son aquí los dos tópicos de esa búsqueda iniciática que el ser humano emprende. Sin embargo, el obstáculo surge para subrayar el peligro de la travesía marítima, incierta y difícil:

Como el soplo del huracán[,]/ vigas de acero

nos conducen a la buena orilla.

Un cielo claro abre sus brazos,

salen pájaros de nidos labrados de nubes,

coronados por azules ventiscas.

Remolinan torbellinos de alas,/ un cóndor sonríe.

Se aclara el tiempo,/ las corrientes se repliegan,

se tornan bitácora del navío

mientras las plumas caen como maná (47).

2 Recordemos que las sirenas, por su carácter híbrido, pasan por monstruos en nuestro imaginario occidental. Su cuerpo biforme (mitad pez, mitad humano) produce miedo y temor (Balavoine, 75).

3 Véase lo que nos dice al respecto Ernest Robert Curtius: «Esa posibilidad de renovación sólo se explica por el hecho de que el tópico está arraigado en lo más profundo del alma, y pertenece a las imágenes arcaicas del inconsciente colectivo. [...] El fenómeno del rejuvenecimiento [...] es el símbolo del ansia de regeneración de la personalidad» (I:158). 
Si el mar tempestuoso es para Gaston Bachelard síntoma de una hostilidad y de ese enfrentamiento del individuo contra el mundo desfavorable, el viento huracanado (en la metonimia «el soplo del huracán») y su consecuencia, el mar embravecido, son el reflejo de esa lucha interior por vencer la adversidad (El agua y los sueños, 240). Así, aunque la experiencia marítima se torne incierta para el marinero o navegante, en Ventura se puede sortear su paso si se cuenta con «vigas de acero» que hagan fuerte el navío. Pasado el efecto del temporal, los cielos se abren, la mirada se proyecta hacia las alturas bajo un cielo protector (en la prosopopeya «Un cielo claro abre sus brazos») y abierto, para que los pájaros vuelen a sus anchas («salen pájaros de nidos labrados de nubes»). El yo lírico contempla el horizonte y se produce ese ascenso de la mirada, tanto en el vuelo de los pájaros como en el viento que propulsa ahora las velas en la dirección acertada («las corrientes se repliegan,/ se tornan bitácora del navío»). La navegación es ahora propicia y segura, mientras el mundo se abre en un vasto horizonte en el que la totalidad y la apertura (Collot, 42) aparecen como las categorías que rigen esta escena marina. Por ello, el éxtasis de la mirada asombrada conduce a una visión exultante:

Un delfín salta el océano/ y en su movimiento corretea la luz.

Se ensarta en la cubierta./ Laten luz y sombra, voladores de fuegos artificiales./ Se prende la fiesta (47).

No es casual que sea el delfín el animal que acompañe al yo lírico, ya que de entre la fauna marina es la única criatura que puede ser filántropa para el marino (Balavoine, 80) y asegurarle su compañía en la navegación. En la escena final de "Viento a babor» domina la intensidad de la luz dentro de un claroscuro que recuerda el espectáculo del paisaje marino de los cuadros del Romanticismo; la celebración a la que asistimos es la que anuncia la posibilidad de llegar al destino final, para quien se conmueva con una naturaleza desplegada como "fiesta». De esa manera, el verbo "prender» no es inocente, destaca ese sentimiento que permea en la profundidad del yo lírico, para que fuego y agua transformen su mirada.

Si la única posibilidad de acceso a lo invisible se produce cuando el poeta descubre y palpa en perspectiva las cosas (Collot, 155), magistralmente Bella Clara Ventura nos va demostrando el dinamismo transformador del agua y de la luz en la exaltación jubilosa de la ensoñación imaginaria. Por lo tanto, ella comprende que la poesía es ante todo una indagación, una empresa introspectiva y de raigambre mística, en cuanto solamente la palabra depurada posibilita la búsqueda del yo poético en el cosmos, de esa luz a la que aspira este poemario.

En «Naves», otro de los poemas de la conjunción del mar y de la luz, el yo lírico es propulsado por el ansia de trascendencia hacia el espacio de los sueños:

Arquitecta de la luz/ me veo al mencionar

a los albañiles de los sueños/ recomponiendo las tinieblas

en naves de ternura (97).

La importancia del motivo de la «nave» ligado al aire y al agua no es nada nuevo; se remonta a los orígenes mismos de nuestra cultura occidental a partir de la «Barca de Caronte», como la ha estudiado Gaston Bachelard en su fundamental libro El agua y los sueños: ensayos sobre la imaginación de la materia. De esa manera, las nociones de fluir y de dinamismo se asocian con el sueño y la muerte, sobre todo a partir del Romanticis- 
mo. Recordemos que, en la estética romántica, «son precisamente el sueño y los demás estados ssubjetivos> los que nos hacen descender en nosotros mismos y encontrar esa parte nuestra que <es más nosotros mismos〉 que nuestra misma conciencia» (Béguin, 29). Ello obliga a que el movimiento de las aguas y el devenir humano se acoplen en ese viaje que, según Bachelard, se trata de "la imaginación profunda, la imaginación material quiere que el agua participe de la muerte; necesita del agua para que la muerte conserve su sentido de viaje» (El agua y los sueños, 118, la cursiva es del original).

Retomando el poema «Naves», el yo poético — femenino, valga la pena ya anotarlo así- se caracteriza a sí mismo como "arquitecta de la luz». Si como plantea Luis A. Jiménez, la arquitectura es «el diseño más visible y público de las Bellas Artes [que] ha causado la atracción de la mirada artística en el mundo de la construcción y la representación del espectáculo» (86), la configuración arquitectónica de «Naves» no debe soslayarse ni pasar desapercibida, pues toda representación de las artes en el espacio convocado aquí privilegia no sólo el sentido de luz sino también el diseño de interiores/exteriores. La oposición entre «luz» y «tinieblas» se dirime a favor de la primera, cuando, como hábil «arquitecta» que posee los planos y sabe dirigir a los «albañiles», puede de nuevo sortear los imprevistos y los peligros de los sueños para que impere la luz. Así, hábil navegante, el yo lírico neutraliza esos sueños tormentosos «en naves de ternura»; ha sabido bogar en la oscuridad y en la incertidumbre.

A continuación se nos presenta, dentro del régimen visual que el poema nos propone, el espectáculo de luces y de sonidos:

Rematan las cadencias/ con el imán de las rutilantes figuras.

Defienden la expresión de la luz/ cuando la fogata estrangula

la silueta de la sombra/ como enemiga espectral.

En un secreto se convierte.

Con su mejor traje surge el enigma/ del solfeo de la estrella en las pupilas en vaivén de los sentidos (97).

Observemos cómo el poema pondera dos sentidos: el oído («Rematan las cadencias») y la vista («surge el enigma/ del solfeo de la estrella/ en las pupilas») se asocian para que Ventura nos proponga sensaciones en las que domina la música («las cadencias/ con el imán de las rutilantes figuras", "del solfeo de la estrella»), lo cual es propio y expresión de la belleza más depurada y refinada que encierra los secretos del poeta desde el simbolismo francés, en tanto juego pirotécnico del lenguaje y de sus formas poéticas. Tanto el sonido como la luminosidad dibujan un decorado en el que la magia de «la fogata» hace surgir ese "secreto» que ahora se va aclarando y se eleva hacia «la estrella», gracias al privilegio maravilloso para las "pupilas» humanas de esa música celeste de la que nos hablan los románticos. Así, esa música espiritual, la música del universo que ofrece sus claves para quien quiera escucharla, se revela en el corazón del poeta y en sus ensoñaciones. La vinculación de la música con las pasiones se establece para quien pueda ahondar en los secretos del alma, ahora encandilada y fulgurante (Abrams, 79). Así, de la visión intuitiva y excepcional a la que nos invitaba «Naves» en ese ascenso de trascendencia, pasamos ahora a la quietud de la vigilia:

Luz y sombra en la encrucijada/ hacen burbujas de olvido.

Se abrazan./ Vence la luz en el vuelo de las luciérnagas

sobre el verdugo,/ la sombra acostada permanece. 
Se agudizan sus partidas,/ quiebran la rutina y rescatan el sábado con las velas encendidas del shabbat,/ magnetismo de la semana en el pabilo del repicar de la luz (97).

El leitmotiv de «luz y sombra» se retoma para que, en su conjunción, no se vean como antagónicos sino dentro de una coincidentia oppositorum. Su contraste dibuja el ambiente temporal, de reposo y de vigilia con el que se cierra el poema, pues del éxtasis de la visión trascendental de los misterios, su transición denota el paso temporal de las horas y el ocaso del día. La escena la rigen «las velas encendidas del shabbat», que forman parte del ritual judaico por el cual se inicia su celebración.

A partir de lo anterior, en "Naves», Bella Clara Ventura superpone en su contigüidad metafórica dos escenas: del sortilegio del nocturno y de la ensoñación gracias a los motivos del agua y del fuego, pasamos a esa transición del día a la noche que marca el tiempo familiar y litúrgico para la conciencia judía de un yo lírico en el que se intensifican la luz y el sonido, porque la imagen disémica, «en el pabilo del repicar de la luz», adquiere doble valor en tanto sinestesia. Por ese motivo en la "encrucijada», ya no en el horizonte, se vislumbra la luz que empieza a irradiar en forma horizontal, razón por la cual «la sombra acostada permanece», mientras la luz se expande verticalmente en esta imagen de lo aéreo ("vence la luz en el vuelo de las luciérnagas»), que entra en equivalencia con la sinécdoque «las velas encendidas del shabbat». "Luz y sombra» se integran en una mímesis perfecta, que ofrece un conjunto creativo capaz de representar el texto y dar su configuración sígnica a la experiencia visionaria de Bella Clara Ventura.

\section{LA VOCACIÓN DEL POETA, LA DIMENSIÓN LUMINOSA DE SU CAMINO}

Así, la vocación del yo lírico se forja en esa significación privilegiada y singularizada que se experimenta en Atisbos de luz, de manera que las cosas no se intuyen en la apariencia ni en su sentido usual, sino en su dimensión luminosa. Ventura percibe el secreto de los símbolos para hacer una síntesis que reenvía de perspectiva en perspectiva a la poeta venturiana y que ilumina esa concepción expresiva de la obra artística, por cuanto desde un punto de vista estético se performa su proceso de contemplación/indagación:

[...] resulta que el contenido expresivo de una obra de arte coincide con lo que el artista ha puesto de sí mismo en ella. Lo que expresa la obra no es sino la actividad expresiva misma, el acto realmente cumplido de expresarse el artista, de revelar su intimidad. Se cumple con ello la sentencia, formulada por Wollheim, de que «la obra de arte expresa lo que la causa». Y lo que la causa es el sentimiento vívido experimentado por el artista (García Leal, 196-197).

Aquello que experimenta el yo lírico en el acto poético lo ilumina en un doble sentido: i) en cuanto proceso de indagación que vuelca el sujeto sobre sí mismo para analizarse y ii) en cuanto contemplación estética que lo obliga a la comprensión del exterior, lugar donde ese ojo interior dimensiona todo como visión y espacio. Así, la integración/absolutización abarcadora de este campo visual crea un axis mundi, de lo inferior hacia lo superior, y transfigura a ese yo lírico del poemario, que se presenta como poeta femenina, en descubrimiento y en avidez del cosmos. Su trayecto vital se establece como si fuera un 
recorrido iniciático en el que lo primero es la concentración reflexiva. Revisaremos dos ejemplos significativos, el primero de los cuales es el poema «Ser de luz»:

Con el otear de la luz/ las sienes me cubro.

Es el hallazgo de nuevas energías./ Me pongo la corona de otro saber, se anida al corazón del resplandor./ Me fundo en un acto de uniones, como caléndulas que sanan,/ eslabones sin sombras (93).

El ritmo logrado por los dos hipérbatos iniciales centra toda la importancia sobre esa luz y lo que desencadena en el yo lírico; la acción del verbo «otear» destaca a cabalidad la importancia de la percepción, mientras que la del segundo, "cubrir», sería la consecuencia de la primera y llevaría a esa acción reflexiva que implica una posición corporal y su disposición para entrar, por otra parte, en actitud reflexiva («las sienes me cubro») 4 . A todas luces convoca una proxémica propia de quien se presta para orar. El efecto es inmediato, hay una transfiguración de parte del yo lírico, donde las «nuevas energías» son sinécdoque de su transformación interior. En «Ser de luz», la luz conduce a la poeta venturiana por nuevos caminos y le imprime "nuevas energías», necesarias en su búsqueda estética. Llama la atención la metáfora «la corona de otro saber», en esa correlación tan prestigiada en nuestra cultura occidental entre «luz»y «saber. La disposición tipográfica privilegia así el proceso iluminativo que provoca una reacción corporal en dos series paralelas:

\section{(Lo exterior)}

Con el otear de la luz

Me pongo la corona de otro saber
(Lo interior)

$\rightarrow$ las sienes me cubro

$\rightarrow$ se anida al corazón del resplandor

Su resultado se enuncia también de la misma manera anterior:
Es el hallazgo de nuevas energías
(Causa)
$\rightarrow$ Me fundo en un acto de uniones
(Consecuencia)

De manera que estamos ante lo que en la experiencia mística denominaríamos la vía unitiva en la que el «saber» y el "corazón» entran en conjunción perfecta de la ciencia y de los afectos para que el milagro ocurra. Así se manifiesta en la continuación de «Ser de luz»:

Convencida,/ inicio la senda de los centelleos.

Se preñan los aires de esperanza,

niña que nace a la luz

cuando todos los seres aplaudimos

la creación sin renunciar

a las semillas de la sombra (93).

Como en todos los poemas de Atisbos de luz, el primer verbo («inicio») está en presente del indicativo, para subrayar el hecho de que la presencia de esa luz transformadora es una acción mentalmente «en coincidencia con el momento en que hablamos» (Gili Gaya, 151), pero también el hecho de que se trata de una acción que desde el punto de vista modal es incoactiva, pues marca el comienzo de cosmos metamorfoseado. En la conciencia

4 Aunque podría verse también como la postura inicial de quien comienza los misterios del shabbat. 
de la hablante, investida de esa luz que la transforma como a todo lo que está a su alrededor, la radicalidad de su experiencia no pasa desapercibida, ni es gratuito entonces que nos aproximemos a lo que Gaston Bachelard llama «imaginación aérea», en ese movimiento de la materia hacia «intuiciones más primitivas» (El aire y los sueños, 298), como podría ser la germinación de las semillas como si se tratara de una nueva "creación». El poder de la luz es concomitante con esa voluntad creadora, para que, exultante, cante sus maravillas, tal y como se realiza en el final de «Ser de luz»:

Cosechamos brillos bajo el prístino sonido

de la metamorfosis

del hombre con alas en el alma

convertido en cuerpo de luz (93).

El mito genésico de la regeneración vuelve a producirse bajo los efectos de este dinamismo, ahora de lo aéreo: «los aires de esperanza» entran en correlación con «del hombre con alas en el alma» (el hipérbaton traduce e intensifica el cambio radical), porque solamente en ese ámbito de descripción de la sinergia, de imágenes de ascensión dinámica, el ser humano puede transformarse en "cuerpo de luz». La dialéctica del aire y del fuego ahora conducen a esa "metamorfosis", pero observemos que se produce bajo el amparo del "prístino sonido" que evoca la creación primordial, de esa música celestial con la que los románticos asociaban las claves de interpretación de lo sensible. Lo anterior desemboca en una poesía que invita hacia la comprensión del exterior, ahí donde ese ojo interior (ese tercer ojo) del poeta asciende para desmontar y componer otra vez en una nueva representación interna (Rorty, 51) . Así, esa música espiritual está allí para las almas sensibles que sepan escuchar su lenguaje y que, en última instancia, solamente se le revela al corazón del poeta (Aguiar e Silva, 328). Entonces, la vinculación de la música y las pasiones se establece para quien pueda ahondar en los secretos del alma (Abrams, 79).

Bajo tales presupuestos, la contemplación estética desemboca en la dimensión metapoética de la indagación que Bella Clara Ventura emprende en Atisbos de luz. Y decimos metapoética por cuanto se trata de «la capacidad [...] de dicho lenguaje para referir su objeto» (Ferrari, 16-17), es decir, de la remisión del poema a sí mismo en cuanto construcción y lenguaje, pues está dirigido hacia sus principios constructivos. La conciencia autorreferencial se manifiesta en la convocatoria de las artes y de la techné, origen de nuestra concepción occidental de la poesía. Al respecto, Neus Galí nos recuerda que esta noción empieza a conformarse en la atención prestada a las destrezas del artesano y a la manera en que utiliza los materiales para moldear sus obras (62), al pulimiento y al trabajo de la forma en las artes figurativas, tal y como sucede en «Atisbo del sol»:

\footnotetext{
«Cuando la poesía y las matemáticas hubieron llegado a la auto-conciencia — cuando hombres como Ión o Teeteto podían identificarse con sus sujetos- llegó la hora de decir algo general sobre el conocimiento de los universales. La filosofía se dedicó a examinar la diferencia entre saber que había cadenas montañosas paralelas que se extendían hacia el oeste y saber que las líneas paralelas no se cruzan aunque se extiendan hasta el infinito, la diferencia entre saber que Sócrates era bueno y saber qué era la bondad. [...] Cuando esta cuestión recibió respuesta en términos de la distinción entre el ojo del cuerpo y el Ojo de la Mente [...] fue identificado como aquello que separa a los hombres de las bestias. [...]. La idea de la ‘contemplación', del conocimiento de los conceptos o verdades universales en cuanto Tewria, convierte al Ojo de la Mente en el modelo inevitable de la forma de conocimiento superior» (Rorty, 44).
} 
Quiero ser alfalera de la luz,/ herrera de la sombra para martillar/ en infinitos sus alas en trompo.

Volver a la orfebrería,/ cancelar el asombro para que se corone en mi ser/ la leyenda de los brillos de lunes colmadas de sonrisas/ y de dulce paladar (71).

En «Atisbo del sol» se manifiesta el acto volitivo de la identidad: el «quiero ser» de todo proyecto vital. De esta manera, la poeta venturiana desea intensamente ser «alfalera de la luz» y «herrera de la sombra». Combinando en el contraste de luz y de sombra lo que hoy denominaríamos como la artesanía, Bella Clara Ventura rescata el componente de trabajo manual que implicaba la techné en su acepción primigenia. La habilidad y la versatilidad del artesano que trabaja las formas (Galí, 49) están al servicio de una concepción que privilegia el trabajo y la producción dentro de ese misterio de luz/sombra, propio por otra parte de la alquimia. Solamente en la forja del material en las transformaciones del fuego, se puede acceder a ese conocimiento privilegiado. Y tal conocimiento se establece como la clave para adentrarse en los secretos de «la orfebrería». Su camino por el lenguaje es un trabajo de pulimiento y de dedicación en la medida en que la poeta, "alfalera» y «herrera», puede alcanzar aquello a lo que aspira. La correlación "orfebrería»/ «corona» viene a subrayar el ámbito de esa búsqueda que encuentra la gratificación en la verdad revelada para el poeta; se desarrolla en ese estímulo/reacción que sepa desencadenar en los seres humanos: las «sonrisas» y el «dulce paladar» de los seres que la rodeen. Así, en la segunda unidad del poema se retoma el motivo del taller de la cocina como espacio también para la fragua de la luz/poesía:

Quiero desnudar mis sinsabores, engolosinar las horas para acudir a la cósmica energía.

Y todos los días plantarla en las venas de la indulgente luz vislumbrando la carcajada de la noche (71).

Vemos, entonces, cómo pasamos del taller del artesano al fogón de la cocina, donde la sinécdoque «dulce paladar» de la unidad anterior constituye el elemento de transición. Ello no es inocente en un poema en el que predomina una concepción del trabajo poético. Recordemos que ya desde el breve tratado de Ión o de La Poesía, Platón asociaba la poesía con el trabajo de las abejas: «Nos dicen [los poetas líricos] que, semejantes a las abejas, vuelan aquí y allá por los jardines y vergeles de las musas, y que recogen y extraen de las fuentes de miel los versos que nos cantan» (96). La antítesis «desnudar mis sinsabores,/ engolosinar las horas", construida sobre la oposición amargo/dulce, apunta hacia ese trabajo de indagación del tiempo, ese tiempo para la celebración exultante de la luz poética y que convoca, como en la versión platónica del origen de la poesía, la "cósmica energía» de la que el poeta es un médium o un celebrante. La imagen final de "Atisbo del sol» es la del rito; la acción se repite («todos los días») para que se instaure el tiempo de la celebración "mimética» de la luz que se impone sobre la noche. La sinécdoque «la carcajada de la noche», con su apelación a lo auditivo/visual, es otra vez sintomática del régimen perceptivo que reclama el conocimiento y la vivencia de lo poético en Bella Clara Ventura. Se trata de la tarea que debe acometer el oficiante de la luz, invocar el sortilegio 
de la poesía y de su contemplación maravillosa en el paisaje absorto, como sucede también en el poema «Cómplice de la luz»:

Donde la flor crece sin agua/ despunta en la tierra crisol de reminiscencias/ un loto de blancura sublime.

Se nutre de adolescentes luces/ como esos seres que miran hacia el cielo/ y de reojo la sombra observan, sábila de otros vuelos sin llegadas (69).

La mirada del yo poético observador se dirige y apela a la inmensidad y a la verticalidad de la percepción sensorial. Con ello, se propone indagar el universo en tanto vasto horizonte en el que el ansia de transcendencia conduce a demarcar un campo visual y un centro radical. Ello crea un axis mundi. Toda manifestación de lo sagrado transfigura este eje de focalización, haciéndolo el lugar de una mostración extraordinaria, cuya revelación es del orden de una centralidad significante. Bella Clara Ventura se transforma en una insaciable buscadora de lugares que le recuerdan ese espacio hierofánico de esencia cósmica, pues de lo que se trata es de «seguir estando en comunicación directa con un «centro» productor de sacralidad» (Chinchilla, 137). El axis mundi, ese centro del mundo ${ }^{6}$, otorga el estatuto simbólico a la percepción visionaria del yo lírico, pues nada comienza sin la orientación de un punto fijo desde el cual el movimiento del cuerpo se libera y se alza la mirada hacia el conocimiento. La proyección de ese axis mundi, que entroniza e instala el centro como eje, se establece por los motivos de «la flor» («un loto de adolescentes luces») y «el cielo». El movimiento del «loto» se dirige, como explica el yo lírico, «hacia el cielo», con lo cual la preposición «hacia» marca la dirección y la perspectiva. Ello es posible en esa convocatoria de planos en la que de lo inferior pasamos a lo superior, de la tierra al cielo.

De esta manera, al trazar la convergencia entre lo telúrico y lo celeste, el universo se ordena y el hombre encuentra el sentido sagrado de las cosas. En «Cómplice de la luz», este elemento vegetal del lotus da forma a lo telúrico y desemboca en lo que Bachelard planteaba como la «intimidad material» de quien atisba el mundo en la concentración de lo minúsculo, porque «en cuanto se trata de soñar o pensar en el mundo de la pequeñez, todo se hace más grande» (La tierra y las ensoñaciones del reposo, 26). Marie-Christine Seguin plantea muy acertadamente que la tierra es sinónimo de profundidad, pero de una profundidad que invita a respirar y a explayarse en lo vertical (496). La existencia de la tierra y de las plantas que la sustentan está orientada hacia el cielo, convirtiéndose en una metáfora del crecimiento de lo que tiene vida, de los deseos más íntimos de ascensión o de esa capacidad del hombre para aspirar a una transformación radical y profunda, en la sinécdoque «sábila de otros vuelos sin llegadas». La imagen visionaria acentúa el desplazamiento de la aventura poética, mientras que de nuevo motivos acuáticos vienen a consumar esa metamorfosis dinámica:

Lágrimas a contraluz/ refleja la lluvia el ojo.

Restablecen la armonía, / cruce de senderos

donde los fluctuantes peces de luz/ el recorrido marcan.

Con miradas fraternas/ en contra picada

Al respecto comenta Chinchilla: «Montañas cósmicas, templos, palacios, ciudades sagradas radican en el centro del espacio sacro. El hombre pretende habitar en tal esfera, de ahí que su propia morada se constituye en el centro de su existencia y, además, en cuanto a lo físico, emula el paradigma hierofánico del axis mundi» (138). 
construyen el faro intuitivo/ de la torre de luz en el atisbo del sol (69).

El recorrido de la vista sigue el trayecto de los «peces». La horizontalidad del mar domina aquí para privilegiar el desplazamiento y el dinamismo que propulsa abruptamente (de ahí los hipérbatos y los encabalgamientos ostensibles que marcan esta última parte del poema) hacia la verticalidad del plano de la percepción: «en contra picada» revela el ascenso vertiginoso desde el mar para explayarse en esa imagen esplendorosa y exultante del «faro», comparado aquí con una «torre de luz»; otro símbolo de la exaltación de la inmensidad divina y de la magnificencia de lo trascendental. Se trata de ese punto de llegada de toda empresa de conocimiento, allí en donde el «ojo» se convierte en el órgano por excelencia de la contemplación.

En conclusión, la experiencia lumínica del horizonte que emprende Bella Clara Ventura se dibuja aquí en esa necesidad de auscultar la inmensidad del universo, para percibirlo en su radicalidad poética (convocar, celebrar, ser traspasado y mirar la luz); de ahí que toda experiencia de los límites de la poesía conduzca al «misterio" y al "enigma», como lo veíamos en el paradigmático poema "Naves». Con ello se nos invita a sopesar y a valorar el dinamismo transformador de la luz en su complemento con el agua fecunda y fluyente. Desde mi punto de vista, ésa sería la clave no sólo para poder ingresar en el universo poético trazado por Bella Clara Ventura, sino también para emprender el camino de esa iniciación estética a la que aspira en la imperiosa luz que la seduce y la conmina a la indagación del universo de lo intangible/tangible. El dinamismo del agua, el movimiento del aire, la germinación de la planta, todos ellos están signados en el universo simbólico de Ventura para que performe el ritual de ensoñación poética a la que la fuerza energética de la luz apunta. Con ello, el poemario pone en escena ese privilegio del ritual y de las "palabras femeninas», que Bachelard asocia con el ámbito del anima (La poética de la ensoñación, 51), en esa felicidad de hablar/mirar, de experimentar el sortilegio de la poesía y de los insondables placeres de su irradiación cósmica. Atisbos de $l u z$ desemboca en un encuentro de Bella Clara Ventura con la propia alteridad del sujeto y con lo trascendente, atemporal y siempre absoluto.

\section{REFERENCIAS}

Abrams, M. H. El espejo y la lámpara: Teoría romántica y tradición clásica acerca del hecho literario. Buenos Aires: Editorial Nova, s.f. Medio impreso.

Aguiar e Silva, Víctor Manuel. Teoría de la literatura. Madrid: Editorial Gredos, 1979. Medio impreso.

Bachelard, Gaston. El aire y los sueños: Ensayo sobre la imaginación del movimiento. México, D. F.: Fondo de Cultura Económica, 1997. Medio impreso.

. El agua y los sueños: Ensayos sobre la imaginación de la materia. México, D. F.: Fondo de Cultura Económica, 2003. Medio impreso.

. La poética de la ensoñación. México, D. F.: Fondo de Cultura Económica, 2004. Medio impreso.

. La tierra y las ensoñaciones del reposo: Ensayo sobre las imágenes de la intimidad.

México, D. F.: Fondo de Cultura Económica, 2006. Medio impreso. 
Balavoine, Claudie. «Au-dessous/ au-dessus de la plaine marine: dichotomie symbolique dans l'imaginaire de l'emblématique espagnole (1581-1640)». L'imaginaire des espaces acuatiques en Espagne et au Portugal. Ed. François Delpech. París: Presses Sorbonne Nouvelle, 2009. 65-97. Medio impreso.

Béguin, Albert. El alma romántica y el sueño: Ensayo sobre el romanticismo alemán y la poesía francesa. Madrid: Fondo de Cultura Económica, 1993. Medio impreso.

Chinchilla Sánchez, Kattia. "Lo sagrado en el espacio y la recurrencia del círculo. A propósito del laberinto, el omphalos y el mandala». Káñina, Revista de Artes y Letras de la Universidad de Costa Rica 24:1 (1999). 137-48. Medio impreso.

Collot, Michel. La poésie moderne et la structure d'horizon. París: Presses Universitaires de France, 1989. Medio impreso.

Curtius, Ernest Robert. Literatura europea y Edad Media latina. México, D.F.: Fondo de Cultura Económica, 2004. Medio impreso.

Ferrari, Marta B. La coartada metapoética: José Hierro, Ángel González, Guillermo Carnero. Mar del Plata: Editorial Martín, 2001. Medio impreso.

Galí, Neus. Poesía silenciosa, pintura que habla. Barcelona: El Acantilado, 1999. Medio impreso.

García Leal, José. Filosofía del arte. Madrid: Editorial Síntesis, 2002. Medio impreso.

Gili Gaya, Samuel. Curso superior de sintaxis española. Barcelona: Bibliograf, 1982. Medio impreso.

Jiménez, Luis A. «Ut Architectura Poesis: La obra de Julián del Casal». Círculo: Revista de Cultura 34 (2005). 86-94. Medio impreso.

Lara-Martínez, Rafael. "La identidad del aire: Poesía y Filosofía en El tránsito de fuego». La palabra innumerable: Eunice Odio ante la crítica. Ed. Jorge Chen Sham y Rima de Vallbona. San José: Editorial de la Universidad de Costa Rica/ Instituto Literario y Cultural Hispánico, 2001. 173-205. Medio impreso.

Pariente, Queli. "La piedra filosofal en Porque es de piedra el corazón de todo, por Juana Alcira Arancibia». La mujer en la literatura del mundo hispánico. Ed. Juana Alcira Arancibia. Buenos Aires: Instituto Literario y Cultural Hispánico, 2005. 217-38. Medio impreso.

Platón. «Ión o de La Poesía». Diálogos escogidos. Buenos Aires: El Ateneo, 1957. 85-108. Medio impreso.

Rorty, Richard. La filosofía y el espejo de la naturaleza. Madrid: Editorial Cátedra, 1989. Medio impreso.

Séguin, Marie-Christine. Des motifs pour dire les quatre éléments dans l'oeuvre poétique de José Lezama Lima. Villeneuve d'Ascq: Presses Universitaires du Septentrion, 2001. Medio impreso.

Torres, Luc. «Boussole à l'usage des navigateurs du frontispice marin de La Pícara Justina». L'imaginaire des espaces acuatiques en Espagne et au Portugal. Ed. François Delpech. París: Presses Sorbonne Nouvelle, 2009. 99-111. Medio impreso.

Ventura, Bella Clara. Atisbos de luz. Bogotá: Editorial Gente Nueva, 2007. Medio impreso.

Recepción: 20 de marzo de 2011 Aceptación: 13 de septiembre de 2011 